\title{
THE SHORT-RUN AND LONG-RUN RELATIONSHIP IN INDONESIAN ISLAMIC STOCK RETURNS
}

\author{
M. Shabri Abd. Madjid
}

\begin{abstract}
The Short-Run and Long-Run Relationship in Indonesia Islamic Stock Returns. This paper aims at empirically examining the short-run and long-run causal relationship between the Indonesian Islamic stock returns and selected macroeconomic variables namely inflation, money supply and exchange rate during the pre-and post- 2008 global financial turmoil period from 2002 until 2007 and from 2008 until 2013 by using monthly data. The methodology used in this study is time series econometric techniques i.e. the unit root test, cointegration test, error correction model (ECM) and variance decompositions (VDCs). The findings showed that there is cointegration between Islamic stock prices and macroeconomic variables. The results suggest that inflation, money supply, and exchange rate significantly affected the Islamic stock returns in Indonesia. These variables should be taken into account by the policy makers as the important policy instruments in stabilizing Islamic stock markets in the country.
\end{abstract}

Keywords: Islamic Stock Market; Money Supply; Exchange Rate; ECM.

\begin{abstract}
Abstrak. Hubungan Jangka Pendek dan Jangka Panjang Pada Tingkat Pengembalian Saham di Indonesia. Tulisan ini bertujuan untuk menguji secara empiris hubungan kausalitas jangka pendek dan jangka panjang antara pasar saham Syariah dengan variabel makroekonomi terpilih, yaitu inflasi, permintaan uang, dan valuta asing di Indonesia pada periode sebelum dan sesudah krisis keuangan global 2008. Data bulanan selama periode sebelum krisis global (2002 - 2007) dan periode setelah krisis (2008 - 2013) dianalisis dengan menggunakan teknis ekonometrik runtut waktu yang terdiri dari uji unit root, kointegrasi, model error correction, dan dekomposisi varians. Hasil penelitian menunjukkan bahwa pasar saham Syariah berkointegrasi dengan variabel makroekonomi. Inflasi, penawaran uang, dan valuta asing berpengaruh signifikan terhadap pasar saham Syariah. Ini menunjukkan bahwa dalam rangka menstabilisasikan dan sekaligus mempromosikan pasar saham Syariah di Indonesia, pengambil kebijakan harus fokus pada pengendalian inflasi, jumlah uang yang beredar, dan valuta asing.
\end{abstract}

Kata kunci: Pasar Saham Syariah; Penawaran Uang; Valuta Asing; ECM. 


\section{Introduction}

Indonesia is one of the countries that is improving very fast during the last few decades. After being hit by the 2008, global financial crisis, the growth of Indonesian economy reached 5-6 percent in 2009-2012. This economic growth rate of the country was higher than those of other large emerging economies such as Indian and China. The Indonesian government had initiated different forms of monetary and fiscal policies to solve the imbalances in the economy during the economic downturns. The monetary policy was selectively unrestricted during the crisis period, with the gradual changes in the general level of interest rates as a measure to counteract fiscal contraction.

During the global financial crisis, the world economic conditions were not that favourable. Instability in the international financial markets in turn spilled over into the Indonesian domestic financial markets. Continued waves of adjustment in both the currency and stock markets, coupled with the decline in domestic and export demand subsequently prompted a shift to more growth promoting policies. One of the institutions that affected was the Indonesian stock markets, both conventional and Islamic.

The major stock exchange in Indonesia is the Jakarta Stock Exchange (JSX). In addition to the existing conventional stock market, the Islamic stock, which is measured by the Jakarta Islamic Index (JII), has been introduced in the country on July 2000. Unlike transactions in the conventional stock markets, any financial dealings in the Islamic stock markets are subject to adhere to the basic rules of trading as outlined by the Shari'ah with the objective of ensuring justice, fairness and avoidance of exploitation. In particular, the Shari'ah provides a clear guideline that financial dealings that involve the elements of interest (riba), excessive uncertainties (gharar) and gambling (maysir) are strictly prohibited. Trading is also not allowable for goods that are prohibited (haram). There is also the need to observe the Islamic $\operatorname{tax}(z a k a t)$.

In this study, we will only focus on an Islamic Stocks which are proxied by the Jakarta Islamic Index (JII). JII is a benchmark for Islamic stock market index that would provide as an accurate performance indicator of the Indonesian Islamic stock market as well as the country's economy. JII consist of 30 stocks based on several criteria established by the Capital Market Supervisory Agency and Financial Institution (Bapepam \& LK) in accordance with the Decree of Bapepam \& LK (2009) on the issuance of shariah securities which then was amended by the Decree of Bapepam \& LK (2012) on criteria and issuance of shariah securities lists. Additionally since 2003, the National Shariah Board (DSN), MUI has issued Fatwa Number: 40/ DSN-MUI/X/2003 on capital markets and general guidelines for the implementation 
of shariah principles in the capital market. Before the 2008 global financial crisis happened, the performance of JII was at the peak level. Nevertheless, during the crisis period, the JII point has declined. During the 2008 global crisis, the Islamic stock markets were also hit adversely by the crisis, as these markets are as vulnerable as other conventional markets to the global financial shocks (Kassim, 2013).

During the post- 2008 of global crisis, there were some encouraging changes in the Indonesian stock markets. The rationale behind these changes was due to the robust global growth during the year resulted in strong demand for electronics and primary commodities. This strong external environment was supported by strong domestic activity as private consumption rose in line with incomes and private investment increased to expand productive capacity to meet demand. Additionally, an increase in private consumption, a revival in the domestic investment and a strong export growth, had helped the economy of the country rebound from the financial crisis. In short, the stability of the macroeconomic variables has contributed to the enhancement of the national stock markets.

An aspect of novelty of this study is that it empirically explores the interaction between the selected macroeconomic variables and Islamic stock markets over the pre-and post-2008 global financial crisis. By considering both the pre-and post-2008 crisis periods, this study could identify the changes in patterns of macroeconomic variables-Islamic stock interactions. Understanding these patterns of interactions among the variables would shed some insightful lights for policy makers and investors. An accurate assessment of the pattern of interactions between the macroeconomic variables and Islamic stocks is important for several reasons. For investors, the design of a well-diversified portfolio crucially depends on a correct understanding of how these variables are interrelated. Changes in the interaction patterns call for an adjustment of portfolios. Policy makers are interested in interactions among these variables because of their implications for the stability of the national financial system. Monetary policy strategy is also influenced by stock market developments, due to the propagation of shocks via equity markets, the wealth channel and confidence effects. The national trend towards a greater role of the Islamic stock market in the economy has made this study more important. Thus, this study is highly relevant and timely due to the fact that shariah-compliance stocks in Indonesia have grown very fast. On the back of a rapid development in the Indonesian Islamic equity market, this study attempts to empirically exploring the determinants of the Islamic stock markets in the periods of pre- and post- 2008 global financial crisis in order to derive and appropriate policy instrument. The macroeconomic variables that theoretically have significant effect on stock market that we have chosen for this paper are inflation rate, money supply, and exchange 
rate. Indeed, there are other variables that affect stock markets, but we limit our discussion on these variables for means of parsimony in modelling as incorporating many variables result in loss of degree of freedom. The findings of this paper are expected to have important consequences for policymakers, international fund managers and other institutional investors who seek to enter the Indonesian stock market for diversification purposes. The rest of the paper is organized in the following sequence: in the next section, the literature survey of relevant studies is provided. The research method and data, on which the analysis is conducted, are presented in Section 3. Section 4 discusses the results and implications of the paper. Lastly, section 5 concludes the paper.

\section{Literature Review}

In an efficient capital market, stock prices adjust rapidly according to the new information available; therefore, the stock prices reflect all information about the stocks. This means that an investor cannot use the readily provided information to predict the stock prices movements and make profits by trading shares. The efficient market hypothesis states that stock prices should contain all relevant information for both policy makers and stockbrokers in the respective industry. We also know that the stock prices reflect expectations of the future performances of corporate and profits. As a result, if stock prices reflect these assumptions in real, then it should be used as a major indicator for the economic activities. Therefore, the dynamic relationship between stock prices and macroeconomic variables can be used to make nation's macroeconomic policies (Maysami et al., 2004).

Mishkin (2007) defined a stock as a security that is claimed on the earnings and assets of corporations (shares of stock) which are traded. This concept is widely used in financial market throughout the world. A stock market index used to monitor the behaviour of a group of stocks.

Gordon Growth Model had simplified the valuation of stock as follow:

$$
P_{0}=\frac{D_{0} \times(1+g)^{1}}{\left(1+k_{e}\right)^{1}}+\frac{D_{0} \times(1+g)^{2}}{\left(1+k_{e}\right)^{2}}+\ldots \ldots . . .+\frac{D_{0} \times(1+g)^{\infty}}{\left(1+k_{e}\right)^{\infty}}
$$

where $\mathrm{D}_{0}$, is the initial dividend paid, $g$ is the expected constant growth rate in dividends and $k_{e}$ is the required return of equity.

This model is useful for finding the stock value with the assumptions that dividend is assumed to continue growing at a constant rate and the growth rate which it is assumed to be less than the required return on equity, $k_{e}$.

The Tobin's $q$ theory tries to relate monetary policy (money supply and interest rates) that can affect the economy through its effects on the valuation of 
equities (stock). Tobin defines $q$ as the market value of the firms, which is highly relative to the replacement cost of capital and new plant as well as capital equipment. Companies can get a higher price for their stock trading relative to the cost of the facilities and equipment. Investment spending will rise because the firms can buy a lot of new investment goods with issuance of new stocks. On the contrary, when $q$ value is low, firm will not purchase new investment goods because market value of the firms is low relative to the cost of capital. When companies want to acquire capital, they can buy another firm in cheaper price and acquire old capital instead. There have been many attempts in the past to find out relationship between stock prices and macroeconomic variables. All these studies have found significant short-run and long-run relationships between stock prices or stock returns and macroeconomic variables. Maysami and Koh (2000) examine the dynamic relations between macroeconomic variables (exchange rate, long and short term interest rates, inflation, money supply, domestic exports, and industrial production) and Singapore stock markets using the vector error correction model, which covered the period from 1988 to 1995 . They found that all the macroeconomic variables have cointegrating relations with the changes in Singapore's stock market levels.

Humpe and Macmillan (2005) study the influence of a number of macroeconomic variables on stock prices in US and Japan. They found the data for US are consistent with a single cointegrating vector, where stock prices are positively related to industrial production and negatively related to both the consumer price index and long-term interest rate. They also find an insignificant (although positive) relationship between US stock prices and the money supply. However, for Japanese data, they found two cointegrating vectors. One vector that stock prices are influenced positively by industrial production and negatively by the money supply. For the second cointegrating vector, they found industrial production to be negatively influenced by the consumer price index and a long-term interest rate.

Mysami et al. (2004) find a positive relationship between inflation rate and stock returns. This is contrary to other studies that suggest a negative relationship. The reason given by the authors is the active role of government to preventing prices escalation after the economy continued to progress after the 1997 financial crisis. The relationship between short-run and long-run interest rate is found to be positive and negative respectively. This is because long-run interest rate serves to be a better proxy for nominal risk-free component, which is used in the discount rate for stock valuation models and may also serve as a proxy for expected inflation in the discount rate. Azman-Saini et al. (2006) in their study by using Granger non-causality found that Malaysian stock prices are led by the exchange rate during the crisis period. During the crisis period, the Malaysian Ringgit depreciated against US dollar and it 
significantly influences the Malaysian stock prices.

Some studies also claim that there are no long-run relationship between stock prices and exchange rates. Bahmani-Oskooee and Sohrabian (1992), Nieh and Lee (2001) conclude that there are no long-run relationship between stock prices and exchange rates. This might be due to different set of variables chosen and also different methods used in the analysis. Ahmed (2008) in his study by using Johansen's approach of cointegration, Toda and Yamamoto approach by using Granger causality test revealed that causal links between aggregate macroeconomic variables and stock indices in the long-run. In addition, Fifield et al. (2002) investigated that the global and local economic factors explain returns in emerging stock markets. Their findings show that local economic variables namely GDP, inflation, money, and interest rates are significant in explaining emerging stock markets.

The positive relationship between stock prices and inflation is also documented in the Pacific-Basin: Australia, Hong Kong, Indonesia, Japan, South Korea, Malaysia, the Philippines, Singapore, and Thailand in Al-Khazali and Pyun (2004). This paper found the negative relationships between stock returns in real terms and inflation in the short-run, while cointegration tests on the same markets display a positive relationship between the same variables over the long-run. They suggest that stock prices in Asia, like those in the U.S. and Europe, appear to reflect a time-varying memory associated with inflation shocks that make stock portfolios a reasonably good hedge against inflation in the long-run.

Unlike the above reviewed studies on the developed and emerging markets, similar study on the Indonesian Islamic stock markets that has been published in the scholarly international journal has been scarce. Only few studies have investigated the relationship between Islamic stock markets and macroeconomic variables (Herwany and Febrian, 2013; Wahyudi and Sani, 2014). In their study, Herwany and Febrian (2013) explored the risk-return behaviour of Islamic stocks and measured volatility of both conventional and Islamic stocks using Value-atRisk (VaR). They found that exchange rate and interest rate significantly affected the portfolio excess return. The Islamic stock portfolio was, to some extent, found to be not consistently immune from the financial shocks, despite the fact that none of macroeconomic variables is significant factor to the change in excess return of Islamic portfolio.

Furthermore, Wahyudi and Sani (2014) investigated VAR Toda-Yamamoto causality test between macroeconomic variables and Islamic financial market and found that the exchange rate has significantly affected Islamic stocks. Using multivariate method, Islamic stocks has more content information of exchange rate, world oil price, and China's economic growth that the interest rate, and 
inflation rate. Additionally, they also found the presence of interaction between the macroeconomic variables, interaction between the financial market and the macroeconomic variables, and interaction between the Islamic capital market and money market.

Unlike the above reviewed studies on the Indonesian Islamic stock market - macroeconomic relations, Beik and Fatmawati (2014) investigated the impact of international Islamic stocks on the Jakarta Islamic Index using the VECM during the period from 2007 to 2012. They found that the Indonesian Islamic stock market was very much influenced by the international Islamic stock markets. Using similar technique of analysis, Pratama (2015) explored the impacts of macroeconomic variables to the performance of Islamic banks in Indonesia for the period 20072012. He found that the performance of Islamic banks having short-term shocks to the innovations of macroeconomic variables, but it become stable in the long-run. However, the innovations of macroeconomic variables only have little impact on the Islamic banking performance.

From the above discussions, it seems that there are long lists of literature on the macroeconomic variables and its effects on the conventional stock market, but there have been limited similar studies focusing on the Islamic stock prices worldwide. Therefore, we find that it is interesting to empirically investigate the effects and inter-relationships between Islamic stock markets and macroeconomic variables in a big-open economy of Indonesia during the pre- and post- 2008 global crisis periods.

\section{Methods}

As mentioned before, this study explores the interaction of Islamic stock price and selected macroeconomic variables, which are inflation, money supply, and exchange rates. Since the global financial crisis has started in July 26, 2007 (Dungey et al., 2008), this study are divided the period of the study into two period, namely the pre-crisis periods starting from June 2002 to June 2007 and the post-crisis periods spanning from January 2008 - January 2013. The selection of these periods is intended to study the effect of pre- and post-crisis, from which the Indonesian market is estimated to have recovered from by the end of 2007. For Islamic stock market (JII), we use the end of the month values of Jakarta Islamic Stock Index (JII). For the inflation, we use CPI (consumer price index) as a proxy to inflation. The money supply (M2) is used as the money supply variable and is expressed in the domestic currency, i.e. Indonesian Rupiah. The exchange rate represented by employing nominal effective exchange rate, the bilateral exchange rate with reference to US dollar. The data are obtained from the IMF's International 
Financial Statistics Database (IFS) and complemented by data from www.econstats. com for various years. The JII is used as it encompasses the largest amount of Islamic stocks traded in Indonesia.

To examine the effect of these variables on stock prices, the generic model applied takes the form as below:

$\operatorname{LnJII~}=\beta_{0}+\beta_{1} \operatorname{LnCPI}+\beta_{2} \operatorname{LnM} 2+\beta_{3} \operatorname{LnER}+\varepsilon_{\mathrm{t}} \cdot$

Before we further analyse the data, the stationarity of the variables test is firstly conducted to avoid the spurious results. There are several methods for testing the presence of unit roots. The most widely used methods are Augmented DickeyFuller (ADF) and Phillips-Perron (PP), which we have both applied in this paper.

In the next step of analysis, after the order of integration of each variable has been determined, we perform the cointegration analysis. This analysis is to determine whether the time series of these variables display a stationary process in a linear combination. For this purpose, the Johansen (1991) method of multivariate cointegration is employed. A finding of cointegration implies the existence of a longterm relationship between the dependent and the independent variables. If there is at least one cointegrating relationship among the variables, then the causal relationship among these variables can be determined by estimating the VECM. The Johansen and Juselius method uses two tests to determine the number of cointegrating vectors (Adebiyi, 2007), namely the "Likelihood Ratio Trace test-LRT" and the "Maximum Eigenvalue test- ME”.

In the next step, the short-run causal relationships between the dependent variable and each of the independent variables are then tested by using Granger Causality tests. A test of causality is to know whether the lags of one variable enter into the equation for another variable (Enders 1995). There are two important steps involved with Granger's Causality test. First, stationary data is needed rather than non-stationary data. Second, in addition to the need to test the stationary property of the data, the Granger methodology is somewhat sensitive to the lag length used. In this paper, the Akaike's information criteria (Granger, 1969,) was used to select the lag length as it is has superiority compared to the other lag length criteria. Finally, after the estimation of the VECM model, then we employ two short-run dynamic analyses called Variance Decompositions (VDCs) for our paper. This analysis allows us to investigate the behaviour of an error shock to each variable on its own future dynamics as well as on the future dynamics of the other variables in the VECM system. VDCs can detect the causal relations among the variables. It explains the degree at which a variable is explained by the shocks in all the variables in the system (Mishra, 2004). 


\section{Results and Discussion}

Table 1 reports the results of the ADF and PP Unit root test, the individual lag is chosen based on the Akaike Information Criterion (AIC). Both tests are conducted with trend and intercept. Except for CPI in the post crisis period, both $\mathrm{ADF}$ and PP tests agree that JII, M2, and ER contain one unit root, in other words they are $\mathrm{I}(1)$ variables at $1 \%$ confidence interval in the pre and post crisis periods. However, for CPI data after crisis, the two tests yield slightly different results. The ADF test suggests that it is not stationary at first difference. Nevertheless, PP test provides evidence more towards stationarity of all variables in their first difference. Since the level of confidence is high (1\%), then for the purpose of this paper, we accept the result of the PP test for LnCPI and conclude that it is stationary at first difference in both periods.

Table 1. The Results of Stationarity Test

\begin{tabular}{ccccccccc}
\hline \multirow{2}{*}{ Variable } & \multicolumn{2}{c}{ Level } & \multicolumn{2}{c}{ First Difference } & \multicolumn{2}{c}{ Level } & \multicolumn{3}{c}{ First Difference } \\
& ADF & PP & ADF & PP & ADF & PP & ADF & PP \\
\hline \multirow{3}{*}{ LnJII } & 0.023 & 0.168 & $0.001^{*}$ & $0.000^{*}$ & 0.0185 & 0.438 & $0.000^{*}$ & $0.000^{*}$ \\
& $(-2.061)$ & $(-2.892)$ & $(-5.536)$ & $(-9.222)$ & $(-2.458)$ & $(-2.292)$ & $(-8.746)$ & $(-8.823)$ \\
LnCPI & 0.011 & 0.015 & $0.011^{*}$ & $0.010^{*}$ & 0.912 & 0.713 & 0.172 & $0.000^{*}$ \\
& $(-1.410)$ & $(-1.516)$ & $(-8.101)$ & $(-11.018)$ & $(-0.765)$ & $(-0.987)$ & $(-3.218)$ & $(-9.610)$ \\
LnM2 & 0.013 & 0.150 & $0.000^{*}$ & $0.000^{*}$ & 0.692 & 0.973 & 0.227 & $0.000^{*}$ \\
& $(-2.847)$ & $(-2.956)$ & $(-9.017)$ & $(-8.908)$ & $(-0.344)$ & $(-0.649)$ & $(-2.728)$ & $(-10.560)$ \\
LnER & 0.153 & 0.523 & $0.000^{*}$ & $0.000^{*}$ & 0.612 & 0.752 & $0.000^{*}$ & $0.000^{*}$ \\
& $(-2.051)$ & $(-2.121)$ & $(-6.458)$ & $(-5.637)$ & $(-1.381)$ & $(-1.675)$ & $(-6.762)$ & $(-6.762)$ \\
\hline
\end{tabular}

Notes: Values based on MacKinnon (1996) one-sided p-values. The value in parenthesis refers to t-statistics, and ${ }^{*}$ indicates significance at $1 \%$.

Having concluded that each of the series is stationary, we proceed to examine whether there exists a long-run equilibrium between the Islamic stock prices and the macroeconomic variables selected. Table 2 provides the Johansen-Juselius Cointegration test results. We set the lag order of first differenced right-handside variables to 4 in the pre crisis and 2 for the post crisis data, using the Akaike Information Criterion (AIC), which we find sufficient to render the error term serially uncorrelated in conducting the test. 
Table 2. The Results of Johansen-Juselius Cointegration Test

\begin{tabular}{ccccccc}
\hline \multirow{2}{*}{$\begin{array}{c}\text { Null } \\
\text { Hypothesis }\end{array}$} & \multicolumn{3}{c}{ System with CR } & \multicolumn{2}{c}{ Critical Values (5\%) } \\
\cline { 2 - 7 } & Trace & Max. Eig & Trace & Max. Eig & Trace & Max. Eig \\
\hline & \multicolumn{2}{c}{ Pre-Crisis } & \multicolumn{2}{c}{ Post Crisis } \\
\cline { 2 - 7 } r $=0$ & $61.1858^{* *}$ & 39.855 & $50.759^{* *}$ & 24.608 & $47.853^{* *}$ & 27.534 \\
$\mathrm{r} \leq 1$ & 15.1870 & 16.187 & 12.117 & 13.754 & 20.707 & 21.162 \\
$\mathrm{r} \leq 2$ & 5.0736 & 4.691 & 12.383 & 11.910 & 15.471 & 14.260 \\
$\mathrm{r} \leq 3$ & 0.4236 & 0.426 & 1.125 & 1.725 & 3.846 & 3.466
\end{tabular}

Note: The lag order specified for the pre and post crisis test is 4 and 2 respectively, which we find sufficient to render the error term serially uncorrelated. The $5 \%$ critical values are based on Osterwald-Lenum (1992).

As may be noted from Table 2, both the maximum eigenvalue and the trace statistics suggests the presence of a unique cointegrating vector at $5 \%$ significant level for the period before crisis. On the other hand, in the period after crisis the maximal eigenvalue statistics did not indicate the presence of cointegration, however the trace statistics showed a unique cointegration between the variables. In this case, we accept the result of the trace statistics as the sample used is quite large. Accordingly, these variables are tied together in the long-run in the period before and after the crisis and their deviations from the long-run equilibrium path will be corrected. The presence of cointegration also rules out non-causality among the variables. In other words, there must be at least a unidirectional causality from one variable to the other. We also report the cointegrating coefficients in long-run equation form normalized on stock prices (LnJII):

Pre-crisis: $\mathrm{LnJII}_{0}=-13.387+8.793 \mathrm{LnCPI}_{0}-3.444 \mathrm{LnM}_{0}+1.789 \mathrm{LnER}_{0}+\varepsilon_{\mathrm{t} 0}$ Post-crisis: $\mathrm{LnJII}_{1}=7.092+4.073 \mathrm{LnCPI}_{1}-0.583 \mathrm{LnM}_{1}-2.565 \mathrm{LnER}_{1}+\varepsilon_{\mathrm{t} 1}$

From the long-run equation of both the period before and after crisis, there seems to be a positive relationship between inflation rate and the price of Islamic stocks. An increase in level of general prices would lead to an increase in the Islamic stock prices since the ownership of stocks representing the ownership of real assets. When the level of inflation increases, investors would expect for higher dividends due to the rise of prices of real assets and in turns would lead to an increase in the prices of Islamic stocks. This result seems to be consistent with Abd. Majid et.al. 
(2001) for the case of Malaysia and Indonesia. This finding supports the view that Islamic stock prices in Indonesia are a good hedge against inflation.

Regarding money supply (M2), the study found a negative association between M2 and Islamic stock prices, for both post and pre crisis periods. According to the Stock Valuation Model and Monetary Portfolio Hypothesis, the increase in money supply leads to a reduction in interest rate, which in turn will increase the price of Islamic stocks. Nevertheless, based on several studies, money supply has an immediate positive response on Islamic stock prices but that effect is dissolved and the long-run association becomes negative. This could be due to the inflationary expectations that future real dividends will be lower, hence decreases the attractiveness of stocks and stock prices in turn will fall (Mukherjee and Naka, 1995 and Dasgupta and Sensarma, 2002). Nevertheless, the positive coefficient for CPI annuls this justification. Therefore, the negative relationship between M2 and Islamic stock prices must be explained using a different framework, that probably an increase in money supply result in inflation uncertainty, leading to depreciation expectation and anticipation of future contractions (Ibrahim and Yusoff, 2001).

As for exchange rate, the pre-crisis long-run equation shows that currency depreciation seems to be associated with an increase in Islamic stock prices. While the post-crisis long-run equation indicates the opposite, meaning that currency appreciation leads to a decrease in Islamic stock prices. In fact, currency effect may have a positive or negative association with Islamic stock prices depending on the nature of the economy. For net-exporting economies, currency depreciation leads to an increase in net exports as domestic products become cheaper in the world market. Hence, the increase in firms' profitability will be reflected in the value of the stocks. However, for economies that depend heavily on imports, currency depreciation may lead to higher import prices causing a fall in firms' profit and in turn the price of stocks. The net effect of currency depreciation will depend on which of these factors is more dominant. In addition, currency depreciation may also create expectations in future increase in the exchange rate, which consequently leads to a fall in the investment flows to the country (Ibrahim and Yusoff 2001). Our result shows that negative net effects are more dominant, hence creating downward pressure on Islamic stock prices. This result is consistent with Ibrahim and Yusoff (2001) and Ibrahim and Aziz (2003) for the Malaysian equity market, and Kwon and Shin (1999) for the Korean case.

The presence of cointegration indicates that at least one of the variables tests react to deviations from the long-run relationship. Here we investigate whether the Islamic stock prices corrects for disequilibrium. Our dynamic causal link between macroeconomic variables and Islamic stock prices can be modeled as: 
$\Delta L n J I I_{t}=h_{0}+h_{1 i} \sum_{i=0}^{1} \Delta L n C P I_{t-i}+h_{2 i} \sum_{i=0}^{1} \Delta L n M 2_{t-i}+h_{3 i} \sum_{i=0}^{1} \Delta L n E R_{t-i}+h_{4 i} E^{\prime}$

where $\mathrm{EC}_{\mathrm{t}-1}$ here is the stock prices error correction, term (lagged residual of statistic regression) and " $\Delta$ " stands for first difference. If the error term is significant, the lagged dependent variables are important in predicting current movements of the stock prices and it also means that stock prices adjust to the previous equilibrium error and that past macroeconomic variables have significant explanatory power for current Islamic stock prices.

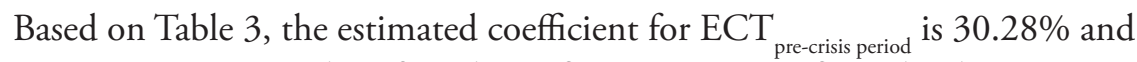
$\mathrm{ECT}_{\text {post-crisis period }}$ is $27.6 \%$ and are found significant at $1 \%$ significant level, suggesting that the last period (month) disequilibrium in Islamic stock prices before crisis is corrected in the next month by $30.28 \%$ while after crisis the disequilibrium is corrected by only $27.6 \%$ in the next month. There seems to be a decline in the speed of adjustment after the crisis, however both values seems to adjust slowly towards the long-run equilibrium. This implies that any shock that forces Islamic stock prices from their long-run value will take a long time for prices to return to its equilibrium unless there are other shocks that counter the initial one.

Table 3. The Results of Error Correction Model of Stock Prices

\begin{tabular}{cccc}
\hline Error Correction & Parameter Estimate & Standard Error & t-statistics \\
\hline ECT $_{\text {pre-crisis period }}$ & -0.302 & -3.618 & $0.083^{*}$ \\
ECT $_{\text {post-crisis period }}$ & -0.275 & -4.780 & $0.057^{*}$ \\
\hline
\end{tabular}

Note: ${ }^{*}$ indicates significance at $1 \%$ level.

After estimating the long-run equilibrium for Islamic stock prices and macroeconomic variables, we investigated the dynamic interactions between these variables. The result of the pair wise Granger Causality with a uniform lag 4 for the period before crisis and 2 for the period after crisis is found to be sufficient to whiten the noise process. From Table 4, some general findings can be concluded. For the period before crisis, we can see that only exchange rate affects Islamic stock prices with bidirectional causality between both variables. However, inflation rate and money supply may have an indirect affect on Islamic stock prices through their affect on exchange rate. Meanwhile, for the period after crisis, the study found that: (i) only money supply and exchange rate affect Islamic stock prices; (ii) there seems to be no causality between Islamic stock prices and inflation; (iii) and there exists a unidirectional causality from money supply and exchange rate to inflation. Based on 
these findings, we can conclude that for the period before crisis, exchange rate leads Islamic stock prices and vice versa, while after the crisis money supply and exchange rate leads Islamic stock prices, but not the other way around. The finding that money supply leads Islamic stock prices are in line with earlier studies conducted on the Malaysian equity market Ibrahim and Yusoff (2001).

Table 4. The Results of Short-run Granger Causality

\begin{tabular}{lcccc}
\hline \multicolumn{1}{c}{ Null Hypothesis } & \multicolumn{2}{c}{ Pre-Crisis } & \multicolumn{2}{c}{ Post-Crisis } \\
\hline & Chi-sq & Prob. & Chi-sq & Prob. \\
LnCPI does not Granger Cause LnJII & 4.858 & 0.308 & 3.877 & 0.155 \\
LnM2 does not Granger Cause LnJII & 6.670 & 0.159 & 5.619 & $0.062^{* * *}$ \\
LnER does not Granger Cause LnJII & 8.162 & $0.088^{* * *}$ & 5.400 & $0.060^{* * *}$ \\
LnJII does not Granger Cause LnCPI & 5.689 & 0.229 & 0.726 & 0.700 \\
LnM2 does not Granger Cause LnCPI & 5.795 & 0.210 & 6.548 & $0.039^{* *}$ \\
LnER does not Granger Cause LnCPI & 11.941 & $0.017^{*}$ & 6.371 & $0.042^{* *}$ \\
LnJII does not Granger Cause LnM2 & 2.175 & 0.700 & 1.686 & 0.452 \\
LnCPI does not Granger Cause LnM2 & 8.643 & $0.082^{* * *}$ & 2.394 & 0.345 \\
LnER does not Granger Cause LnM2 & 1.571 & 0.756 & 1.702 & 0.473 \\
LnJII does not Granger Cause LnER & 10.584 & $0.034^{* *}$ & 0.543 & 0.744 \\
LnCPI does not Granger Cause LnER & 0.260 & 0.960 & 0.074 & 0.934 \\
LnM2 does not Granger Cause LnER & 17.578 & $0.001^{*}$ & 0.006 & 0.964 \\
\hline
\end{tabular}

Note: ${ }^{*}, * *,{ }^{* * *}$ indicates significance at $1 \%, 5 \%$, and $10 \%$ level, respectively.

Finally, the results of variance decomposition pre- and crisis period are reported in Table 5 with variance decomposition at 3, 6, 9, and 12 month horizon. The findings suggest the presence of interaction among the variables. We observe that variations in Islamic stock prices are predominantly attributed to its own variations, accounting for $99.20 \%$ in the period before the crisis and $85.47 \%$ for the period after the crisis of the JII forecast error variance after 3 months. Compared to other variables in the first two quarters of the period before crisis, money supply explains most of the variation in Islamic stock prices counting for $11.59 \%$, followed by inflation rate by $5.64 \%$. However exchange rate does not have a short-run impact in the variation of Islamic stock prices, it only shows significant effect in the end of the year, counting for $2 \%$ of the variation. However, the results after the crisis show different dynamics of interaction between these variables. In the first quarter, inflation explains relatively higher fraction of the JII forecast error variance by $12.97 \%$, followed by money supply with $8.74 \%$. Exchange rate has a tendency to capture the variation in the first semester 
Al-Iqtishad: Jurnal Ilmu Ekonomi Syariah (Journal of Islamic Economics) Vol. 8 (1), January 2016

of the year, but at the end of the year exchange rate forecast error variance is around $28.52 \%$, accounting for the highest percentage among the other variables, followed by inflation (11.5\%) and money supply (6.64\%).

Table 5. The Results of Variance Decomposition

\begin{tabular}{|c|c|c|c|c|c|}
\hline \multirow[t]{2}{*}{ Variable Explained } & \multirow{2}{*}{ Period } & \multicolumn{4}{|c|}{ By innovation in (\%) } \\
\hline & & LnJII & LnCPI & LnM2 & LnER \\
\hline \multicolumn{6}{|c|}{ Pre-crisis Period } \\
\hline \multirow[t]{4}{*}{ LnJII } & 3 & 99.225 & 3.231 & 0.495 & 0.297 \\
\hline & 6 & 82.293 & 5.640 & 11.589 & 0.477 \\
\hline & 9 & 73.509 & 4.593 & 20.679 & 1.217 \\
\hline & 12 & 70.457 & 4.039 & 23.469 & 2.032 \\
\hline \multirow[t]{4}{*}{ LnCPI } & 3 & 0.735 & 87.812 & 11.311 & 0.140 \\
\hline & 6 & 0.559 & 67.120 & 30.105 & 2.214 \\
\hline & 9 & 1.452 & 64.020 & 33.160 & 1.366 \\
\hline & 12 & 1.585 & 64.686 & 32.512 & 1.215 \\
\hline \multirow[t]{4}{*}{ LnM2 } & 3 & 13.117 & 16.591 & 69.999 & 0.291 \\
\hline & 6 & 17.700 & 15.046 & 65.946 & 1.305 \\
\hline & 9 & 22.522 & 12.851 & 62.165 & 2.461 \\
\hline & 12 & 24.697 & 11.583 & 60.688 & 3.031 \\
\hline \multirow[t]{4}{*}{ LnER } & 3 & 1.985 & 1.401 & 5.303 & 91.308 \\
\hline & 6 & 2.496 & 1.036 & 7.751 & 88.716 \\
\hline & 9 & 2.456 & 1.294 & 12.511 & 83.737 \\
\hline & 12 & 3.277 & 2.153 & 13.460 & 81.108 \\
\hline \multicolumn{6}{|c|}{ Post-crisis Period } \\
\hline \multirow[t]{4}{*}{ LnJII } & 3 & 85.470 & 8.607 & 4.179 & 1.742 \\
\hline & 6 & 75.923 & 8.607 & 4.179 & 1.742 \\
\hline & 9 & 65.847 & 12.968 & 8.738 & 2.369 \\
\hline & 12 & 53.348 & 13.226 & 8.191 & 12.734 \\
\hline \multirow[t]{4}{*}{ LnCPI } & 3 & 0.683 & 11.495 & 6.637 & 28.519 \\
\hline & 6 & 2.011 & 87.208 & 5.165 & 6.942 \\
\hline & 9 & 2.896 & 75.897 & 9.580 & 12.510 \\
\hline & 12 & 3.364 & 69.800 & 11.411 & 15.891 \\
\hline \multirow[t]{3}{*}{ LnM2 } & 3 & 1.484 & 66.535 & 12.343 & 17.756 \\
\hline & 6 & 0.900 & 9.519 & 87.866 & 1.130 \\
\hline & 9 & 0.590 & 8.512 & 88.496 & 2.089 \\
\hline & 12 & 0.478 & 8.043 & 89.474 & 1.891 \\
\hline \multirow[t]{4}{*}{ LnER } & 3 & 0.063 & 7.762 & 90.176 & 1.581 \\
\hline & 6 & 0.954 & 0.010 & 2.330 & 97.595 \\
\hline & 9 & 1.964 & 0.054 & 1.507 & 97.483 \\
\hline & 12 & 2.598 & 0.144 & 0.933 & 96.956 \\
\hline
\end{tabular}

Note: Cholesky Ordering: LnJII, LnCPI, LnM2, and LnER 
On the other hand, JII capture captures most variations on money supply accounting for $24.69 \%$ at the end of the year, which is considered high, followed by the exchange rate $(3.28 \%)$ which is not that significant. In the period after crisis, however, it seem that JII does not capture much variations on the macroeconomic variables discussed, except for CPI (3.36\%) which is also not considered high. While inflation responds to both shocks in exchange rate and money supply, each explaining $15.89 \%$ and $11.41 \%$ of the forecast error variation of CPI at the end of the year, respectively. These results are consistent with the Granger-Causality test that has been conducted earlier. In the same time, forecast error variation in M2 is attributable in a substantial portion to inflation with $7.76 \%$ after 12 months. From these results, we can say that dynamics of interaction between macroeconomic variables and Islamic stock prices seems to be different from the period before and after the crisis. This could be due to changes in policy taken by the government to reform policy target effectiveness and curb volatility in Islamic stock prices. Nevertheless, we can conclude from our results that exchange rate, money supply, and inflation rate can all be regarded as good candidates to be observed and controlled by the government in order to stabilize Islamic stock prices.

\section{Conclusion}

This study empirically explored the determinants of Islamic stock market in Indonesia both from short- and long- run perspectives during the pre-crisis (20022007) and post-crisis periods (2008-2013). The findings indicated that money supply, inflation, exchange rate, and Islamic stock market share a long-run relationship in both periods deviations in the short-run stock returns would be adjusted towards the long-run value. However, from the value of the error correction model $30.28 \%$ before crisis and $27.6 \%$ after crisis, we can say that this adjustment was slow unless there are other shocks that occur at the same time and counter the initial shock. This result signals the importance of these variables as government targets to emphasize policy effects on stock market.

Furthermore, the long-run equilibrium indicates that there is a positive relationship between inflation rate (CPI) and Islamic stock prices. This is in line with other studies conducted on the Malaysian equity market for the period before the economic crisis (Ibrahim and Yusoff (2001), Ibrahim and Aziz (2003) and Islam (2003). This indicates that the feature of Indonesian Islamic stock prices as being good hedges against inflation stands even after the crisis. As for money supply (M2) - Islamic stock relation, they study found it to be negative, finding which is in line with Ibrahim and Yusoff (2001) and Ibrahim and Aziz (2003). The negative relation between money supply and Islamic stock market can be due to increase in inflation 
uncertainty that may lead to decrease in Islamic stock prices. As for exchange rate, there is different pattern of interaction in the period before and after crisis. Before crisis, the long-run relationship was positive, while in the period after crisis there was negative association indicating that negative currency effect net effects are more dominant, hence creating downward pressure on Islamic stock prices. This also showed that the Indonesian economy is open for international trade. The results of the variance decomposition indicated that Islamic stock prices respond to innovations in exchange rate and money supply positively in the short-run, but the effect become negative in the long-run. This finding helped in giving input to the government in employing exchange rate policies as in the case of emerging markets adverse repercussions on equity markets may occur (Abdalla and Murinde, 1997; and Ibrahim and Yusoff, 2001). The findings showed that inflation, money supply and exchange rate are still good variables to be emphasized on by the government as financial policy instruments in order to stabilize Islamic stock prices.

\section{References}

Abd. Majid, M.S., et.al. (2001). The Relationship between Stock Returns and Inflation: Evidence from Malaysia and Indonesia. Capital Market Review. Vol. 9 (1), pp. 129-154.

Abdallah, I.S.A. \& Murinde, V. (1997). Exchange Rate and Stock Price Interactions in Emerging Financial Markets: Evidence on India, Korea, Pakistan and the Philippines. Applied Economics, Vol. 7 (1), pp. 25-35.

Adebiyi, M. A. (2007). Does Money Tell Us Anything About Inflation in Nigeria? Singapore Economic Review, Vol. 52 (1), pp. 117-134.

Ahmed, S. (2008). Aggregate economic variables and stock markets in India. International Research Journal of Finance and Economics. Vol. 14, pp. 141-164.

Al-Khazali, O. M. \& Pyun, C. S. (2004). Stock Prices and Inflation: New Evidence from the Pacific-Basin Countries. Review of Quantitative Finance and Accounting. Vol. 22, pp. 123-140.

Azman-Saini, W.N.W, et.al. (2006). Stock Prices, exchange rates and causality in Malaysia: a Note. The ICFAI Journal of Financial Economics, Vol. 5, pp. 7-13.

Bahmani, O. M., \& Sohrabian, A. (1992). Stock prices and the effective exchange rate of the dollar. Applied Economics, Vol. 24, pp. 459-464.

Beik, I.S, \& Fatmawati, S.W. (2014). Pengaruh Indeks Harga Saham Syariah International dan Variabel Makro Ekonomi Terhadap Jakarta Islamic Index. Al-Iqtishad: Journal of Islamic Economics. Vol. 6 (2), pp. 155-178. 
Dasgupta, P. \& Sensama, R. (2002). Monetary Policy and Predictability of Stock Return Evidence from a Liberalizing Economy Indira Ghandi. Institute of Development Research, pp. 1-22.

Dungey, M., Fry, R, et.al. (2008). Are financial crises alike?, Working Paper, No. 15, Centre for Applied Macroeconomic Analysis, Canberra, pp. 1-58.

Enders, W. (1995). Applied Econometric Time Series. Toronto: John Wiley and Sons.

Fifield, S.G.M., et.al. (2002). Macroeconomic factors and share returns: An analysis using emerging market data. International Journal of Finance and Economics. Vol. 7, pp. 51-62.

Granger, C.W.J. (1969). Investigating Causal Relations by Econometrics Models and Cross Spectral Methods. Econometrica, Vol. 37 (3), pp. 424-438.

Herwany, A., \& Febrian, E. (2013). Portfolio Volatility of Islamic and Conventional Stock: The Case of Indonesia Stock Market. Paper Presented at the 9th International Conference on Islamic Economics and Finance (ICIEF): Growth, Equity and Stability: An Islamic Perspective, 9-11 September, Istanbul, Turkey.

Humpe, A. \& Macmillan, P.D. (2005). Can macroeconomic variables explain long term stock market movements? A comparison of the US and Japan, CRIEFF Discussion Papers 0511, Centre for Research into Industry, Enterprise, Finance and the Firm.

Ibrahim, M \& Yusoff. (1999). Macroeconomics Variables and Stock Price in Malaysia: an Empirical Analysis. Asian Economic Journal, Vol. 13 (2), pp. 219-231.

Ibrahim, I. \& Jusoh, M.A. (2001). The Causes of Stock Market Volatility in Malaysia", Paper Presented at the Malaysian Finance Association 3rd Annual Symposium, Kuala Lumpur.

Ibrahim, M \& Aziz. (2003). Macroeconomic Variables and the Malaysian Equity Market. Journal of Economic Studies, 30, 6-27.

Islam, M. (2003). The Kuala stock market and economic factors: a general to-specific error correction modeling test. Journal of the Academy of Business and Economics, accessed November 23, 2012, [available at http://eprints.uum. edu.my/438/1/Loo_Hooi_Beng.pdf].

Johansen, S. (1991). Estimation And Hypothesis Testing of Cointegrating Vectors in Gaussian Vector Autoregressive Models. Econometrica. Vol. 55, pp. 251-276.

Kassim, S.H. (2013). Global Financial Crisis and Integration of Islamic Stock Markets in Developed and Developing Countries. Asian Academy of Management Journal of Accounting and Finance. Vol. 9 (2), pp. 75-94.

Kwon, S.K. \& Shin, T.S. (1999). Cointegration and causality between macroeconomic variables and stock market returns. Global Finance Journal, Vol. 10, pp. 71-81. 
MacKinnon, J. G. (1996). Numerical Distribution Functions for Unit Root and Cointegration Tests. Journal of Applied Econometrics. Vol. 11, pp. 601-618.

Maysami, R. C. \& Koh, T. S. (2000). A Vector Error Correction Model of Singapore Stock Market. International Review of Economic and Finance. Vol. 9, pp. 79-96.

Maysami, R.C., et.al. (2004). Relationship between Macroeconomic Variables and Stock Market Indices: Cointegration Evidence from Stock Exchange of Singapore's All Sector Indices. Jurnal Pengurusan. Vol. 24, pp. 47-77.

Mishkin, F. (2007). The Economics of Money, Banking, and Financial Market. Boston: Pearson.

Mishra, A. K. (2004). Stock Market and Foreign Exchange Market in India: Are They Related? South Asia Economic Journal. Vol. 5, pp. 209-221.

Murkherjee, T.K. \& Naka, A. (1995). Dynamic Relations between Macroeconomic Variables and the Japanese Stock Market: An Aplication of Vector Error Correction Model. The Journal of Financial Research. Vol. 18 (2), pp. 223-237.

Nieh, C.C. \& Lee, C.F. (2001). Dynamic relationship between stock prices and exchange rates for G-7 countries. The Quarterly Review of Economics and Finance. Vol. 41, pp. 477-490.

Osterwald-Lenum, M. (1992). A Note with Quantiles of the Asymptotic Distribution of the Maximum Likelihood Cointegration Rank Test Statistics. Oxford Bulletin of Economics and Statistics. Vol. 54 (3), pp. 461-72.

Pratama, Y.C. (2015). Macroeconomic Variable and Its Influence on Performance of Indonesian Islamic Banking. Al-Iqtishad: Journal of Islamic Economics. Vol. 7 (1), pp. 60-72.

Toda, H.Y. \& Yamamoto, T. (1995). Statistical Inference in Vector Autoregression with Possibly Integrated Process. Journal of Econometrics, Vol. 66 (1), pp. 225-250.

Wahyudi, I., \& Sani, G. A. (2014). Interdependence Between Islamic Capital Market and Money Market: Evidence from Indonesia. Borsa Istanbul Review. Vol. 14 (1), pp. 32-47. 